\title{
Rural Savings: Their Magnitude, Determinants, and Mobilisation
}

\author{
B. A. AZHAR
}

\section{INTRODUCTION}

The general view about the rural population in Pakistan is that a vast majority of it has a deplorably low standard of living. The incomes of most of the rural people are so low that one wonders how they manage to survive. Studies on poverty in the country show that the incidence and the intensity of poverty in the villages is much higher than in the towns. Yet the available data about rural incomes and family budgets show that the average propensity of the rural households to save is much higher than the national average. Several questions need to be answered in this regard. Are the data about rural incomes and expenditures reliable? Are the findings a consistent feature over time or only a temporary phenomenon for a year or so? Do only larger farmers save or do the smaller peasants and non-farm rural people also manage to save? Is this finding unique only to our rural populace or is there evidence of similar findings from elsewhere? What is the possible rationale for this unusual saving behaviour? What is the magnitude of rural savings and what could be their role in rural development? Finally, how could these savings be encouraged and mobilised?

This paper aims at exploring and answering these questions with the help of whatever data are available. Apart from the Introduction, the paper is divided into five sections. In the first section, we present evidence of high rates of rural savings in Pakistan and some other countries. Section 2 discusses the rationale of this savings behaviour and the determinants of rural savings. In Section 3, we examine the magnitude of rural savings and their possible role in rural development. Section 4 deals with the problem of mobilisation of rural savings. The final section sums up the discussion.

\section{RATES OF RURAL SAVINGS IN PAKISTAN}

Before presenting evidence on rural savings, it would be appropriate to define savings. Economic theory tells us that saving represents the difference between income and consumption. Income includes earnings from all sources during a year and is net of costs incurred in producing that income. (Imputed costs, however,

B. A. Azhar retired as Dean of the Faculty of Agricultural Economics and Rural Sociology, University of Agriculture, Faisalabad. 
constitute income of the farm family). Consumption is the total amount of goods and services consumed by the rural household during a year and includes expenditure on food, clothing, housing, heat and lighting, travel, education, health care, social ceremonies and recreation, litigation and charity, etc. Savings may be made in kind, such as jewelry, land, livestock or dowry, or may be in the form of currency notes deposited in a bank (or, more often, hoarded).

Detailed information on farm and non-farm incomes and household expenditures is available for Punjab since 1949-50, not for every year but on a periodical basis. This information was collected by the Board of Economic Inquiry, Lahore till 1976 and has since been collected by the Punjab Economic Research Institute (PERI), Lahore. The information is collected from selected rural families by the record method by trained enumerators who are stationed in the villages for data collection. There is careful supervision of the field staff by senior research staff. The sample of the selected families has, however, been changed from time to time to reflect changes in the economic conditions in the province. The sample, though small, is selected through a multi-stage sampling technique. The sample comprises small, medium, and large farm households in irrigated and rain-fed areas; and nonfarm households of village artisans, agricultural labourers, and the village shopkeepers.

We present below, in Table 1, data on rural savings for farm households for four years, taken at random in the past four decades. These years include: 1966-67, 1976-77, 1986-87, and 1991-92. The main purpose of the table is to show the high rates of savings of various categories of farmers particularly of small farm households. It is neither intended nor is it possible to study trends in the rates of

Table 1

\begin{tabular}{lcccc}
\multicolumn{2}{c}{ Savings Rates of Farm Households in the Punjab (Pakistan) } & (Percent) \\
\hline Farm Size & $1966-67$ & $1976-77$ & $1986-87$ & $1991-92$ \\
\hline Large & 57.8 & 42.9 & 42.1 & 52.5 \\
Medium & 42.7 & 17.0 & 17.8 & 37.4 \\
Small & 27.0 & 49.6 & 12.9 & 20.0 \\
Average & 48.7 & 29.3 & 18.0 & 32.3 \\
\hline Households & 54 & 62 & 602 & 980 \\
\hline Source: & For 1966-67, Farm Accounts and Family Budgets, The Board of Economic Inquiry, Lahore. For \\
the other years, Farm Accounts and Family Budgets, Punjab Economic Research Institute, \\
Lahore. For $1967-68$, the categories in the first column are: Big Land-owners, Peasant \\
Proprietors, and Tenant Cultivators. Big land-owners had more than 6 hectares, peasant \\
proprietors 3 to 6 hectares, and tenant cultivators 2.4 to 21 hectares. For the other years, large \\
units had more than 10 hectares, medium units had between 5 and 10 hectares, and small units \\
had less than 5 hectares. Savings rate is the ratio of net farm family savings and net farm family \\
income derived from all sources.
\end{tabular}


savings with data only for four random years. It needs to be mentioned that the sample size in the first two years is rather small. It is only in the last (and the latest) year that the size of the sample appears to be adequate for statistically valid conclusions.

It will be observed that large farmers had very high rates of savings: this could be expected. What is surprising is the savings behaviour of small and medium farm households. Their saving rates too have been high in almost all these years. ${ }^{1}$

Is this savings behaviour abnormal? Is it peculiar only to Pakistan? We shall now have a look at evidence from other countries.

\section{Evidence on Rural Savings from Other Countries ${ }^{2}$}

The data from other countries available with us are somewhat old; nevertheless it will serve our limited purpose to show whether rural households in other countries also have high propensities to save. We have evidence in this regard from Taiwan, Japan, South Korea, Malaysia, India, and some African countries.

\section{Taiwan}

High-quality and detailed information collected by farm record-keeping shows that APS (defined as the ratio obtained by subtracting the total annual value of household consumption from total net household income and dividing by total net household income) for all households ranged from 19 percent to 31 percent for the 1960-1974 period. The APS among even the smallest farm size households was large, ranging from 13 percent in 1962 to 22 percent in 1974. The large farmers (with farm size 2 hectares or more) had savings rates ranging from 24 percent to 39 percent during the same period. Clearly, the evidence from Taiwan supports the findings in Pakistan.

\section{Japan}

Although Japan is a high-income, developed country, its rural household data show similar savings behaviour of small farm households. The data on household incomes and expenditures was collected by Farm Household Economic Survey and not by the record-keeping method. Because of this, there was probably some underreporting of income. Still, the APS for the average farm household ranged between 10 percent and 22 percent during 1950-73. The APS of large farm households ranged between 15 percent and 24 percent, and that of small households between 6 percent and 21 percent during the period 1950-1973. (The APS equals total disposable income minus gross household expenditure, including depreciation on household capital goods divided by total disposable income). This too confirms our findings in Pakistan.

${ }^{1}$ Data reported in Government of Pakistan (1990), show much lower saving rates owing probably to under-reporting of incomes.

${ }^{2}$ Information about rural savings in other countries is based on Adams (1978). 


\section{India}

In India, a large number of studies have been done on rural savings. Information from studies on rural savings in the Indian Punjab is presented in Table 2 below:

Table 2

Savings Rates of Farm Households by Farm Groups

\begin{tabular}{|c|c|c|c|c|c|c|c|c|}
\hline \multirow{3}{*}{$\begin{array}{l}\text { Farm } \\
\text { Size }\end{array}$} & \multicolumn{4}{|c|}{ Ludhiana District } & \multicolumn{4}{|c|}{ Hissar District } \\
\hline & 1966- & 1967- & 1968 & $1969-$ & 1966- & 1967- & 1968- & 1969 \\
\hline & 67 & 68 & 69 & 70 & 67 & 68 & 69 & 70 \\
\hline Small & 2.0 & 6.0 & 6.0 & 17.0 & 1.0 & 9.0 & 34.0 & 34.0 \\
\hline Medium & 17.0 & 23.0 & 30.0 & 26.0 & 21.0 & 21.0 & 38.0 & 36.0 \\
\hline Large & 18.0 & 22.0 & 28.0 & 25.0 & 9.0 & 17.0 & 37.0 & 31.0 \\
\hline Average & 14.0 & 20.0 & 25.0 & 24.0 & 12.0 & 18.0 & 37.0 & 34.0 \\
\hline Households & 72 & 72 & 72 & 72 & 108 & 108 & 108 & 108 \\
\hline
\end{tabular}

Source: A. S. Kahlon and Harbhajan Singh Bal, "Factors Associated with Farm and Farm Family Investment Pattern in Ludhiana (Punjab) and Hissar (Haryana) Districts, 1966-67 through 196970". Unpublished report [Ludhiana: Department of Economics and Sociology, Punjab Agricultural University, n.d. (ca 1971)]. In Ludhiana, small units had less than 3.5 hectares, medium sized units 3.5 to 6.0 hectares, and large units more than 6.0 hectares. In Hissar, small units had less than 4 hectares, medium sized units 4 to 8 hectares, and large units had more than 8 hectares.

It can be noted that the average rate of savings of farm households has been quite high. The savings rates of medium-sized farm units have been remarkably high-and higher than even the large-sized farms. In some years, savings rates of even the smallest size farm groups were quite high. It shows that Pakistan's experience is neither unique nor abnormal.

\section{Korean Evidence}

The annual Household Income and Expenditure Surveys carried out by the Korean Ministry of Agriculture and Fisheries provide clear evidence that savings rates of all farm households ranged from 4 percent in 1965 to 33 percent in 1974. As in the data of other countries, the APS among households with small farms was surprisingly large, ranging from nearly 9 percent in 1962 to almost 26 percent in 1974. It would be noted that savings rates increased substantially from 1965 to 1974 . It was partly due to increased farm incomes and partly due to doubling of the rate of interest applied to deposits, raising nominal rates on time deposits to 30 percent in September 1965. The real rates of interest rose to more than 8 percent on financial savings.

Evidence from Malaysia too suggests that significant savings capacity exists among the surveyed rural households. Studies carried out in Zambia also show that, on the average, the rural households included in the studies were saving more than 
30 percent of their income. There is also similar evidence available from some other African countries. It is, however, sufficient to show that rates of savings amongst rural households are significantly high. One could expect such high rates of savings from the relatively large farms but the existence of high savings rates amongst the smallest farmers presents an enigma which needs to be explored.

\section{RATIONALE FOR AND DETERMINANTS OF RURAL SAVINGS}

The general impression that the subsistence farmers are too poor to save seems to be unfounded. What are the factors which motivate small farmers to save? In Pakistan at least, the role of the interest rate policy and financial institutions in encouraging rural savings is negligible. What then is the rationale for this savings behaviour? This is an area in which not much work seems to have been done. It would appear that the small farmers manage to save in two ways: first, they increase their meagre incomes by 25 to 30 percent by non-farm incomes which come from off-farm work, business, and service; second, they squeeze their consumption expenditure on items which are not essential for survival. Household expenditure is broadly classified as (a) food expenditure and (b) non-food expenditure. Food expenditure can be further divided into (i) cereals and (ii) non-cereals. Peasants generally cannot cut down on cereals as their consumption is essential for their survival. The daily per capita requirement of wheat is about 450 grams on average, irrespective of the farm size. The poorer households cannot economise on this item as it provides the minimum necessary calories for survival. What they can economise on are the non-cereals such as milk and milk products, meat, fruit, and other protective foods. They do not save out of income left after meeting their optimum consumption needs. They save by cutting down their basic needs. Some idea of this can be had from their consumption pattern shown in Table 3 below:

Table 3

\begin{tabular}{|c|c|c|c|c|c|c|}
\hline Category & Food & Clothing & Housing & Medicine & Education & All Other \\
\hline \multicolumn{7}{|l|}{ Large } \\
\hline Farmers & 52 & 12 & 12 & 1 & 4 & 19 \\
\hline Medium & & & & & & \\
\hline Farmers & 65 & 11 & 10 & 1 & 2 & 11 \\
\hline \multicolumn{7}{|l|}{ Tenants } \\
\hline Farmers & 67 & 11 & 5 & 1 & 2 & 14 \\
\hline
\end{tabular}

Source: Government of Punjab (1971). 
It will be observed that in 1968-69 nearly two-thirds of the consumption expenditure of poor households is on food. The expenditure on medicines, education, fuel, lighting, religious and social functions, and recreation, etc., is very small. The consumption pattern has virtually remained unchanged through the years. In 1986-87, for instance, the percentage expenditure of small farmers on food was 65 percent of their total consumption expenditure. It would appear that the poor squeeze savings out of their food and non-food expenditure as an insurance for their survival. Another reason for their saving may be their inability to borrow at all or the likely liability to pay exorbitant rates of interest.

In the western economic literature, several reasons have been given for personal savings. In general, the higher the rate of interest, the greater the rate of savings. The Korean experience bears this out. There are, however, personal reasons for saving which are independent of the rate of interest. For instance, most people save to have a reserve to meet unforeseen contingencies. Many people also save to meet some future requirement such as funds for old age, education of children, or to by or build a house. The old-age insurance and hire-purchase system tend to reduce voluntary saving on these accounts. Well-off people save to have wealth and power and use these for prestige. The very-rich have unplanned savings out of their very high incomes. Some of these reasons would appear to be also relevant to the situation in rural Pakistan.

A rationale is sometimes suggested for a possible low rate of savings in the rural households. It is argued, for instance, that large households with several generations living together are presumed to internalise many of the insurance activities that would otherwise necessitate savings. This should lead to a low rate of saving. In the first place, joint family system is fast breaking up. Secondly, income from agriculture is inherently unstable, and with the subdivision of land holdings, uncertainty at low levels of incomes becomes a real threat to survival. This necessitates saving out of low incomes despite the joint family system.

\section{MAGNITUDE OF RURAL SAVINGS AND THEIR MOBILISATION}

The rural savings, though high in rate, are small in individual amounts and scattered amongst millions of small savers. Only a small percentage of the village people have access to banking institutions. All others hold their savings in the form of currency notes (which are sometimes destroyed by white ants!), jewelry, cattle, grain or some other commodity. Much of the hoarded saving is unproductive and risky. If these savings could be pooled, almost the entire credit requirements of the agriculture sector could be met. At present, the institutional credit goes mainly to the large farmers who often default on repayment, jeopardising the survival of the lending institutions. The credit requirements of most of the small farmers and of 
non-farm population are met from non-institutional sources at exorbitant rates of interest. If the rural household savings could be successfully mobilised, not only would the credit requirements of the smaller farmers and non-farm population be met, but also an impetus would be given to village economic development with larger production, setting up of small enterprises, and further increase in savings.

Assuming that the rates of saving in other provinces of Pakistan are as high as in the Punjab, one could venture a rough estimate of the total magnitude of rural savings. If we assume the overall average rate of saving to be 15 percent of the GNP of agricultural origin, the aggregate size of rural savings could be put provisionally at Rs 50 billion. This is more than three times the size of institutional credit at present.

\section{MOBILISATION OF RURAL SAVINGS}

For the rural population, their savings are perhaps the most precious asset. The safety of these assets is their primary concern. Many people would not entrust their savings to the financial institutions unless they are assured that they are safe there. The first requirement of course is to provide banking outlets in the rural areas. Secondly, government should insure bank deposits up to a certain level. This would go a long way in attracting the wary villagers to the financial institutions. As the interest rate policy cannot be recommended as a potent instrument in an Islamic society, an equally effective policy will be to value-link savings to price changes, especially when the inflation rate is as high as 15 percent-20 percent. The credit facilities from the banking outlets should be linked with the opening of a bank account. The villagers are very intelligent and practical people. If they find their savings secure with purchasing power protected at conveniently-located banking outlets, and with facilities to get credit, they would flock to the financial institutions. The villages will have their own modest capital base which should open many doors for future prosperity.

\section{SUMMING UP}

The general impression that the majority of rural population with too low incomes is unable to save anything needs to be corrected. The pessimism that the case of the rural poor is beyond hope also needs to be removed. The majority of the rural people have high rates of savings necessitated by their will to survive. If these savings could be successfully mobilised through policies suggested in the earlier paragraphs, the pessimism about rural poverty could change into vigorous optimism. There is a need for further research to explore the motivation behind high saving rates, the forms in which savings are held and utilised, and the effects of high rates of savings (out of consumption expenditure) on the health, education, productivity, and quality of life in general of small farmers. 


\section{REFERENCES}

Adams, Dale W. (1978) Mobilising Household Savings through Rural Financial Markets. Economic Development and Cultural Change 26:3.

Pakistan, Government of (1990) Household Income and Expenditure Survey, 198788. Karachi: Federal Bureau of Statistics.

Punjab, Government of (1971) Farm Accounts and Family Budgets of Cultivators in the Punjab, 1966-67 and 1967-68. Lahore: The Board of Economic Inquiry 


\section{Comments}

This paper is an attempt to deal with various aspects of rural savings, such as the reliability of rural income and expenditure data, consistency of saving ratio over time, relationship between farm size and saving ratios, rationale of saving behaviour, and the issues regarding the mobilisation of rural savings. Given this broad scope of the paper, the author has followed, quite wisely, a rather simple methodology. His approach is to provide the empirical evidence regarding rural savings and then come up with an explanation of the observed saving behaviour of the rural household.

The principal finding of this study is that rural households do save irrespective of the size of their landholdings, and that their saving performance is better than the national average. I have no problem with this result as evidence from different countries points to this fact. The paper is interesting reading but one that requires some fine-tuning. In particular, I have a few questions regarding Table 1 and the analysis that follows. First, the discussion based on Table 1 gives the impression as if the analysis were based on absolute levels of rural savings. However, this is not the case. Table 1 provides data on the saving ratio (or APS), defined as a ratio of net farm family savings to net family income. If one follows this definition, then it is not clear whether high saving ratios are owing to higher net farm family savings or due to low net farm family incomes. Similarly, it is ambiguous whether the changes over time in the savings ratios are due to the changes in net savings, net income, or both. Second, even if one overcomes the above problem, the use of Table 1 to analyse trends in saving ratios poses another difficulty that has weakened the analysis. The author compares the absolute values of saving ratios over time to conclude that rural savings have been on the rise for the period under consideration. This conclusion, however, ignores the fact that in order to analyse the saving ratios over time, one needs to consider the changes in the saving ratios rather than compare their absolute values.

To provide the rationale of rural household savings the author uses 1960s data (Table 3) on the rural household consumption pattern. I, however, consider it inappropriate to use 1968-69 data to explain the consumption behaviour in 1990s; particularly when the consumption patterns in rural Punjab have gone through a major transformation due to the inflow of international remittances since the early 1970s. Also, I strongly feel that while explaining the rationale of savings behaviour in Pakistan one must incorporate the implications of the cost of borrowing for farm household saving decisions. 
The last two sections of the paper provide valuable suggestions to mobilise rural savings for development purposes in the rural areas, and the author deserve much credit for these.

Department of Economics,

Amir Mahmood

University of Newcastle, NSW,

Australia. 